\title{
Article \\ The Impact of Renewable Energy Sources on the Economic Growth of Poland and Sweden Considering COVID-19 Times
}

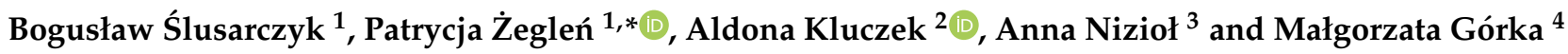 \\ 1 Institute of Economics and Finance, Social Sciences College, University of Rzeszów, Rzeszów, 1, \\ Ćwiklińskiej Street, 35-601 Rzeszow, Poland; boguslaw.slusarczyk@gmail.com \\ 2 Faculty of Mechanical and Industrial Engineering, Institute of Production Systems Organization, Warsaw \\ University of Technology, 86, Narbutta Street, 02-524 Warsaw, Poland; aldona.kluczek@pw.edu.pl \\ 3 Institute of Physical Culture Sciences, Medical Sciences College, University of Rzeszów, Rzeszów, 2A, \\ Cicha Street, 35-959 Rzeszow, Poland; aniziol@ur.edu.pl \\ 4 Commodity Science Unit, Carpathian State College in Krosno, Rynek 1, 38-400 Krosno, Poland; \\ malgorzata.gorka@kpu.krosno.pl \\ * Correspondence: pzeglen@ur.edu.pl
}

Citation: Ślusarczyk, B.; Żegleń, P.; Kluczek, A.; Nizioł, A.; Górka, M. The Impact of Renewable Energy Sources on the Economic Growth of Poland and Sweden Considering COVID-19 Times. Energies 2022, 15 , 332. https://doi.org/10.3390/ en15010332

Academic Editor: Ricardo J. Bessa

Received: 30 November 2021

Accepted: 28 December 2021

Published: 4 January 2022

Publisher's Note: MDPI stays neutral with regard to jurisdictional claims in published maps and institutional affiliations.

Copyright: (C) 2022 by the authors. Licensee MDPI, Basel, Switzerland. This article is an open access article distributed under the terms and conditions of the Creative Commons Attribution (CC BY) license (https:// creativecommons.org/licenses/by/ $4.0 /)$.

\begin{abstract}
A demonstration of the relationship between the share of renewables in gross marginal energy and selected countries' economic growth is the basis of this research. The paper seeks to investigate mutual correlations between renewable energy sources and economic growth for two EU economies and how it influences their fluctuations (increase and decrease). The comparative analysis of results was carried out for less-income Polish and high-income Swedish economies. This research used a regression model to answer the research questions examining the presence of correlations between renewable energy sources in gross marginal energy consumption and economic growth. This study analyzes data starting from 1991 to 2022. The results indicated a positive correlation (statistical significance) between Gross Domestic Product and Gross National Income variables for Sweden ( $84.6 \%$ and $83.7 \%$, respectively) and Poland (79.9\% and $79.2 \%$, respectively), which influence the use of renewable energy sources. The findings also reveal that the higher economic growth caused by the use of renewables is observed for the leading countries but at the same time the risk of a greater recession is much more likely than in other countries. These findings would help government officials and policymakers to better understand the role of renewable energy in the economic growth of these countries. This study has contributed to the literature on renewable energy sources and statistical reports under the EU energy sector framework.
\end{abstract}

Keywords: economic growth; renewable energy sources (RES); Gross Domestic Product (GDP); Gross National Income (GNI); regression model; Poland; Sweden; COVID-19

\section{Introduction}

The growing "green" paradigm to minimalize energy use and its effect on climate change highlights the necessity for shifting from a fossil-based economy to renewablesbased economy or bio-based economy [1]. However, the transformation process might go well delivering regular statistical data collection if not for unexpected events such as COVID-19, which disturbs and causes uncertainty in the evaluation of a factor's impact on the economic growth of both developing and developed countries.

The main motivation for writing the paper is to analyze the impact of three key issues regarding renewable energy sources (RES) and its influence on two coefficients, Gross Domestic Product (GDP) and Gross National Income (GNI), of Poland and Sweden. Moreover, because of existing unpredictable phenomena that are called "Black Swans" in the economy, the issues were examined considering the COVID-19 (perceived as the "Black Swan") era. The paper aims to examine correlations between renewable and economic growth in Poland and Sweden, improving the quality of the debate about RES and their 
influence on GDP and GNI from a COVID-19 perspective. The authors stated that the higher the share of RES, the better the economic growth and higher the GDP and GNI indicators. This choice of countries was made due to the existence of significant differences between them, not only economically but also related to renewable energy sources; this being the reason why the research concerning Sweden and Poland (no other well-developed and developed countries) is a randomized trial conducted among well-developed and developed European countries. To back the choice up, it is worth underlining that, in Sweden, the share of renewable energy in the gross marginal energy consumption in 2020 was over $92 \%$. In turn, over $82 \%$ of the energy production in Poland is the energy obtained from non-renewable sources [2]. Additionally, another reason for choosing these two countries is a similar situation regarding economic growth, as the GDP ratio in 2015-2019 was at the given level. We also selected a variety of methods and research, performed to analyze the relationship between these countries, but mainly to investigate the impact of economic growth on the creation of power plants powered by renewable energy sources.

Over the years, several studies have been undertaken to investigate the correlations between RES and economic growth formulated in GDP and GNI indicators. The interconnections were mostly found as positive relations [3-10], and supported by technological innovations [11].

Similar research was carried out in various countries in terms of economy and policy [12-18], but the problem of influencing RES on the less-income Polish and high-income Swedish economies has not yet been addressed in this considered area. Hence, the authors of the paper tried to formulate a research gap, which is the lack of a casual interconnection between the energy-based economic factors (energy-GDP and energy-GNI) impacting the economic growth of these countries. Then, the relations are compared to each other to reveal the economic welfare gap with emphasis on COVID-19. In this study, the two variables considered are interdependent, but the research was carried out under various configurations of the variables (as per the level of dependency). To extend the current research in the field of RES, the authors put the main research questions as follows: (1) Is there a relationship between the share of RES in gross marginal energy consumption and economic growth? (2) Do the identified variables interact with each other using a regression model? These research questions were determined in relation to the research gap defining the problem statement.

The goal of the study is to examine the impact of the energy-related variables (GDI and GNI) on the level of economic growth in Poland and Sweden. Through the regression model, this research is intended to demonstrate an impact of renewable energy sources on the economic development through countries' economic factor structures. The selection of countries was based on data availability in EUROSTAT, World Bank and Internet reports, to provide a balanced sample and specifically for the environmental and political conditions and their successful establishment in the national markets. In addition, the selected countries to be analyzed should also outline the importance of RES, which is distributed unequally across the European Union countries (Sweden and Poland). According to the ranking of the Responsible Development Index and the 2019 Sustainable Development Report $[19,20]$, Sweden was rated very highly amongst the world's most developed economies. Poland occupies a stagnating position regarding affordable and clean energy, thus not meeting the Sustainable Development Goals from the 2030 Agenda [21].

This article presents a linkage between the significant energy-related factors influencing the economic growth of Poland and Sweden-two distinct countries in terms of economy, policy, tradition, culture, location, etc. The current state of the research conducted in different parts of the world and in various countries has been carefully reviewed [17,22-26]. In the light of the reviewed literature, the authors of this paper derived the inspiration and need to treat/consider the research from a COVID-19 perspective. The perspective seems to be very important because it influenced all the spheres of our lives and made a contribution to decrease the GDP and GNI in all the countries. The paper is an attempt to disseminate the effects on the structure of the energy sector across the last 20 years, also considering the 
COVID-19 pandemic, with a particular emphasis on the use of renewable energy sources. To meet the goal set out in the literature review, a regression model was used.

The paper is structured as follows: Section 1 includes introduction, Section 2 outlines the literature review, which explains the relations between the components of energy-based economic growth under constraints such as COVID-19. Section 3 covers the conceptual framework that defines the impact of RES on the economic growth of Poland and Sweden. Section 4 presents the research outcomes, followed by the recommendations implied by these results and the energy policy implication for economic growth. Section 5 states the discussion and Section 6 covers conclusions.

\section{COVID-19 and Renewable Energy Sources-Literature Review}

The crisis changed consumer behavior, which resulted in a reduction in the level of fossil fuel consumption in favor of an increase in demand for renewable energy. Regarding the energy sector, the impact of the crisis and the associated policy responses are reinforcing the existing trends in renewable energy, with leaders continuing to use renewable energy, while countries heavily dependent on the fossil fuel industry spend government spending on supporting these sectors, which additionally slows down the clean energy transition [27]. Pandemic restrictions in many countries did not affect electricity production from renewable sources. Global renewable energy consumption in all sectors increased by $1.5 \%$, while renewable electricity production increased by almost $3 \%$ in the first quarter of 2020 compared to the same period in 2019. It resulted from new wind and solar PV projects completed within the last year and the fact that renewable energy sources have low marginal operating costs. As a result, the share of RES in electricity demand has increased in many regions affected by the pandemic blockade, including parts of Europe and the USA [28]. With the COVID-19 pandemic starting in 2020, RES accounted for as much as $90 \%$ of the added energy in the energy sector. The most significant contribution to such a large increase was made by photovoltaics and hydro and wind energy. According to the International Energy Agency (IEA) report [29], if the current trends continue until 2025, renewable energy will become the most significant energy source. It will meet a third of the global energy demand. Moreover, most of the shares of companies related to the sector doubled in value compared to December 2019. However, the COVID-19 pandemic provides unique information on how different societies are coping with emergencies and how the higher share of RES compared to traditional fuels will affect grid infrastructure, energy markets, and related investments [30-32]. Indeed, the lessons learned from the crisis will shape new policies and determine the long-term consequences for a more sustainable future. Achievements in industrial production have contributed to the increased use of fossil fuels on a large scale, making the energy sector a vital sector of most economies in the world. A disturbing phenomenon is the rapid depletion of oil, gas, and coal resources, which has significantly contributed to by the increase in the world's population, which, according to the United Nations forecasts, will reach the level of 10.9 billion by 2100 . Moreover, the extraction of these raw materials becomes more complex and requires advanced technological solutions, which translates into an increase in costs and prices. Thanks to the growing awareness of the dangers of a fossil fuel-based energy, humanity has once again turned to solutions that use renewable energy. Extensive analysis of the literature concerning correlations between renewable energy sources and the economic growth of various countries is presented in this paper. Many countries (including Sweden, Finland, and Denmark [33], Bulgaria [34], Croatia [35], Estonia [36], the Czech Republic [37], Greece [18], and others) are changing their energy policy [2] because it has occurred to them that the renewables may (among others) constitute a way to strike a balance between economic growth and the quality of the environment. It is confirmed, among others, by EUROSTAT data, according to which the share of renewable energy sources in the energy policy of most countries from 28 countries has increased, and 12 European Union members have already achieved the target of a $20 \%$ share of energy from renewable sources in the gross final energy consumption in the community in 2020. With the growing level of RES use by Euro- 
pean countries, an in-depth analysis of the impact of various factors on this phenomenon is present in numerous publications [38-40]. In the group of factors there are listed increases in oil prices caused by geopolitical threats, the necessity of climate changes mitigations, increase in energy security, GDP, and elimination of carbon-intensive fuels. Peculiarly high carbon dioxide $(\mathrm{CO} 2)$ emissivity as a result of using traditional energy sources as well as economic growth measured in GDP are the main reasons why separate countries change their energy policy and use RES [41-43]. Moreover, the empirical findings show that an ever-greater use of renewable energies may sustain the economic growth process and have a positive significant impact on GDP improvement and economic development, not only in European and well-developed countries, but [44-46] also in SAARC countries (South Asian Association for Regional Cooperation) [47] and Latin American countries [48,49]. This novel empirical research resulted in creating a new energy policy to reach goals in the area of sustainable economic growth in many countries, especially in EU countries. Therefore, RES consumption plays a determining role in improving economic growth in numerous European and non-European countries. Scientists confirm that the exploitation of renewable energy sources brings many benefits, such as reducing environmental pollution, reducing the consumption of fossil fuels, and reducing the costs of energy production and supply [50-52]. In view of the foregoing, Europe is gradually moving away from non-renewable energy sources in favor of "green energy", the share of which in Europe's energy sector is increasing even in the face of the crisis caused by the COVID-19 pandemic. Mandatory quarantine contributed to a significant decrease in environmental pollution by reducing the consumption of fossil fuels in favor of increasing the demand for renewable energy sources [53-56]. The research undertaken by scientists allowed to assess the impact of the coronavirus pandemic on the energy sector, also in terms of investment and use of renewable energy [46-48]. Such an acceleration of activities can offset the harmful effects of the COVID-19 global pandemic. Despite the crisis caused by the COVID-19 pandemic in 2020, which affected many industries, including the energy sector, the increase in renewable energy was observed, especially wind and solar energy [27]. Global power of RES (that constitute almost $30 \%$ in all the energy mixture) increased to about $260 \mathrm{GW}$ [57]. The International Energy Agency (IEA) [17] also reports on the excellent condition of RES. Despite the disturbances in the energy sector due to the pandemic, in the first quarter of 2020 (i.e., in the conditions of the ongoing pandemic), only renewable energy sources recorded a $1.5 \%$ increase in demand with a parallel decrease in demand for coal, oil, and natural gas. Many authors [57-59] wrote about the essential maintenance of the growth in demand for renewable energy in the conditions of lockdown and pandemic constraints. The most significant decrease in demand by approx. 15\% concerned electricity, especially in countries where strict health restrictions were introduced. Forecasts indicate that the demand for fossil fuel sources will continue to decline. Only the demand for renewable energy sources will increase, which means a favorable prognosis for this energy field [19]. The coronavirus pandemic and the global crisis it causes, combined with climate threats, made it necessary to adjust the energy policy to include renewable sources of electricity. The introduction of renewable energy sources into the energy sector by many countries has become a priority in their policy of building energy security. When comparing Poland and Sweden with respect to energy policy, one has to emphasize that Sweden is the undisputed leader in the energy transformation rankings [60]. Unfortunately, Poland is placed 69th (between Bolivia and Indonesia). Sweden was using RES in 33\% of its total energy production in 1990, and the aim of using "green energy" in 50\% (planned for 2020) was achieved in 2012. Sweden aims to support domestic energy use by total use of RES, and they want to achieve the goal in 2040. The importance and the growing share of renewable energy sources is also one of the sustainable targets for Poland within its energy policy [61]. As an EU target, the energy policy assumes a 21-23\% increase in the share of renewable energy sources in the energy mix by 2030 [20]. Additionally, the report addresses the carbon share in energy production (it is going to be decreased up to $60 \%$ whereas today it is $80 \%$ ), and the RES share in the oil and energy sector will equal 28.5\% in 2040 [62]. The relationships between 
the components of energy-based economic growth under constraints such as COVID-19 is outlined in Figure 1.

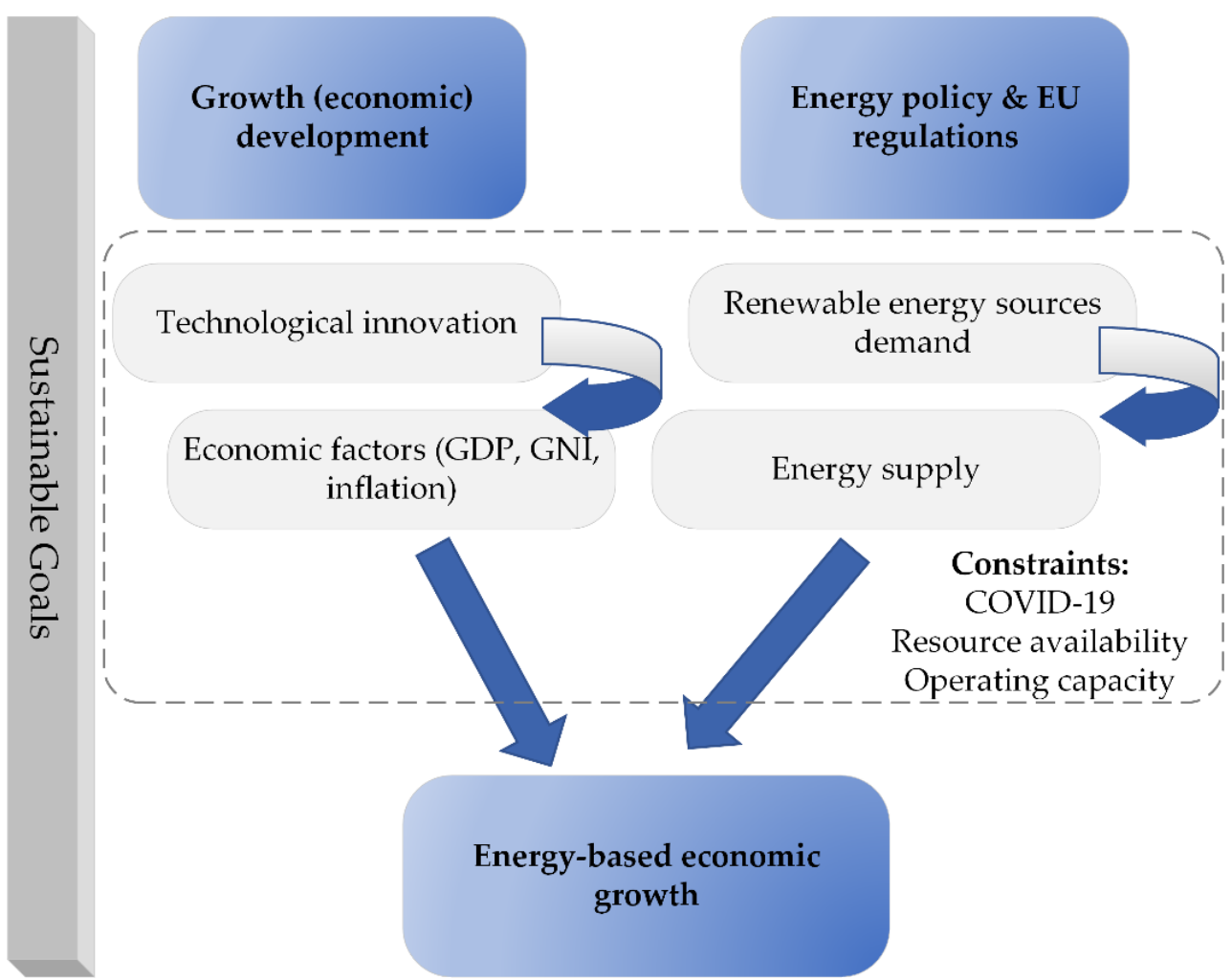

Figure 1. Energy-based economic growth. Source: Own elaboration.

The foregoing literature review concerning correlations between the renewable energy sources and economic growth of various countries regarding the COVID-19 pandemic constitutes a background for the research analyzing two different countries with various energy resource sharing coefficients in their final use of gross energy (Poland and Sweden). These countries were selected considering a highly developed economy against a lessdeveloped one to identify the gross energy consumption disparities between them. Usually, these analyses are being carried out to compare extremely developed countries (with less-income vs. high-income economy) or for developing countries [54]. Data analyses through the use of a regression model will allow solving the problem of an "asymmetrical distribution" of renewable energy sources between both countries.

\section{Materials and Methods}

The study uses the data from EUROSTAT and the World Bank selected by the researchers. The idea is to show to which extent the impact of RES occurs in developed countries, which are characterized mostly by Gross Domestic Product and Gross National Income.

In this paper, the authors used a conceptual framework for defining the impact of RES on the economic growth of Poland and Sweden, as presented in Figure 2. It consists of the following stages:

1. Problem statement based on the literature review and observations of the economic situation in Europe.

2. Selection of countries using a randomized trial performed by the authors of the paper.

3. Analysis of the energy-related economic variables based on available reports, scientific papers, and statistical data from EUROSTAT and the World Bank, which was a basis for the calculation of a correlation coefficient. For the analysis, GDP, GNI, and RES were taken to calculate the correlation coefficients considering the impact of RES on the 
economic growth for the variables for Poland and Sweden. Fundamental indicators, such as standard deviation and coefficient of determination, were also analyzed.

4. Building a regression model, we find the relations between the economic variables, with the use of the time series method. Moreover, to analyze the economic variables in a proper way, the authors have divided the variables into endogenous (RES) and exogenous (GDP, GNI) ones. STASTISTICA 13.1 software was used to obtain the research results. The steps required to carry out and validate the variables are as follows:

4.1. Analysis of various regression models in the literature on the considered topic $[16,63,64]$;

4.2. Linear regression model was applied to find correlations between the analyzed economic variables;

4.3. The regression model used in the study is a kind of panel data fixed-effects regression model denoting the GDP, GNI, and RES variables;

4.4. Responsiveness to changes of the variables' creation was obtained in the final step of analysis.

5. Comparative analysis of the results in terms of the three selected economic variables' correlations for both countries.

6. Results discussion.

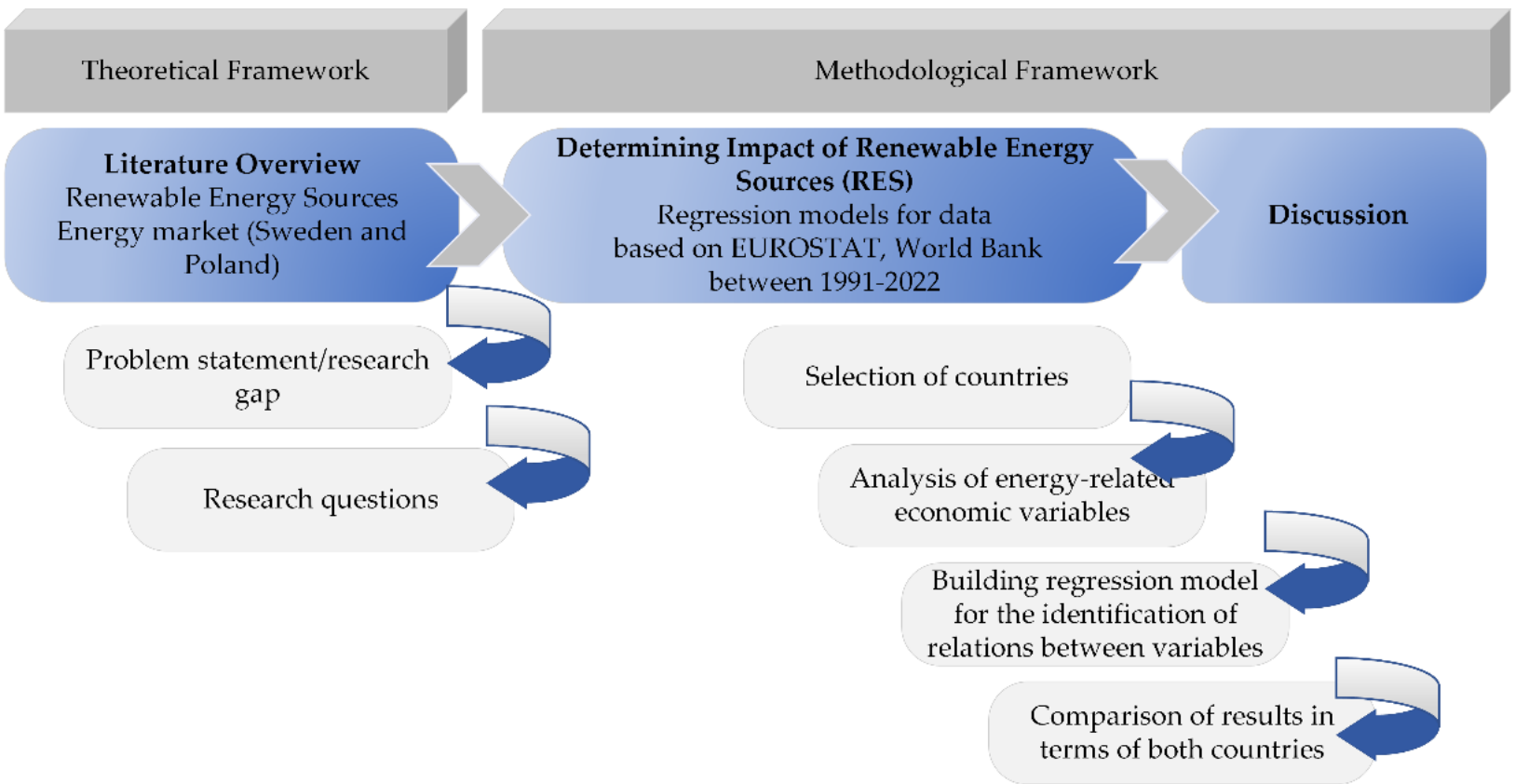

Figure 2. The proposed conceptual framework for determining the impact of RES on the economic growth.

Having this schematic structure of the study, a correlation coefficient between the renewables and economic growth for Sweden and Poland can be investigated. The research uses time interval series data starting from 1991 to 2022.

Having the linear regression model built, the authors could identify the relations between the variables to carry out and validate them. The authors of the paper referred to other works that used similar regression models with a fixed-effects approach in the context of renewables use and its impact on economic growth $[16,63,64]$. 


\section{Results}

The researchers focused their analysis on the relations between three variables (GDP, GNI, and RES), which means that it was investigated whether the changes in the shaping of the $\mathrm{X}$ variables (GDP and GNI) influenced the changes in the $\mathrm{Y}$ variable (RES).

Table 1 shows the results of the correlation coefficients between the variables GDP, GNI, and RES and gross final energy consumption in Poland and Sweden from 1991 to 2020, as well as the prognosis made for 2021 and 2022.

Table 1. Coefficients of the Gross Domestic Product (GDP), Gross National Income (GNI), and renewable energy resources (RES) share in the final use of gross energy.

\begin{tabular}{|c|c|c|c|c|c|c|c|c|}
\hline \multicolumn{3}{|c|}{$\begin{array}{l}\text { \% Share of Renewable Energy in } \\
\text { Gross Final Energy Consumption }\end{array}$} & \multicolumn{3}{|c|}{ Gross Domestic Product (GDP) } & \multicolumn{3}{|c|}{ Gross National Income (GNI) } \\
\hline Years & Poland & Sweden & Years & $\begin{array}{l}\text { Poland (Billion } \\
\text { Dollars) }\end{array}$ & $\begin{array}{l}\text { Sweden (Billion } \\
\text { Dollars) }\end{array}$ & Years & $\begin{array}{l}\text { Poland (Billion } \\
\text { Dollars) }\end{array}$ & $\begin{array}{l}\text { Sweden (Billion } \\
\text { Dollars) }\end{array}$ \\
\hline 1991 & 2.06 & 32.46 & 1991 & 85.50 & 271.98 & 1991 & 82.65 & 265.72 \\
\hline 1992 & 2.3 & 33.23 & 1992 & 94.34 & 281.99 & 1992 & 90.34 & 272.06 \\
\hline 1993 & 6.13 & 34.39 & 1993 & 96.05 & 211.21 & 1993 & 92.55 & 202.59 \\
\hline 1994 & 6.19 & 31.35 & 1994 & 110.80 & 227.27 & 1994 & 109.81 & 221.47 \\
\hline 1995 & 6.33 & 33.91 & 1995 & 142.14 & 265.39 & 1995 & 140.14 & 259.83 \\
\hline 1996 & 5.86 & 31.36 & 1996 & 159.94 & 289.76 & 1996 & 158.87 & 283.99 \\
\hline 1997 & 5.98 & 35.62 & 1997 & 159.12 & 266.38 & 1997 & 157.99 & 261.16 \\
\hline 1998 & 6.54 & 35.66 & 1998 & 174.39 & 268.92 & 1998 & 173.20 & 265.02 \\
\hline 1999 & 6.41 & 34.79 & 1999 & 169.72 & 272.29 & 1999 & 168.71 & 271.86 \\
\hline 2000 & 6.93 & 40.01 & 2000 & 171.89 & 261.34 & 2000 & 171.16 & 261.50 \\
\hline 2001 & 7.21 & 37.66 & 2001 & 190.52 & 241.02 & 2001 & 189.91 & 241.20 \\
\hline 2002 & 7.49 & 36.15 & 2002 & 198.68 & 265.34 & 2002 & 198.01 & 266.10 \\
\hline 2003 & 7.29 & 34.91 & 2003 & 217.51 & 332.27 & 2003 & 215.41 & 337.90 \\
\hline 2004 & 6.914 & 38.677 & 2004 & 255.10 & 382.62 & 2004 & 246.98 & 384.80 \\
\hline 2005 & 6.9 & 40.72 & 2005 & 306.12 & 389.75 & 2005 & 300.78 & 395.09 \\
\hline 2006 & 6.888 & 42.447 & 2006 & 344.75 & 420,22 & 2006 & 337.48 & 431.20 \\
\hline 2007 & 6.93 & 43.929 & 2007 & 429.06 & 487.97 & 2007 & 414.66 & 502.69 \\
\hline 2008 & 7.713 & 44.666 & 2008 & 533.82 & 515.41 & 2008 & 524.47 & 533.27 \\
\hline 2009 & 8.661 & 47.88 & 2009 & 439.80 & 435.11 & 2009 & 426.59 & 445.35 \\
\hline 2010 & 9.253 & 46.958 & 2010 & 479.32 & 495.33 & 2010 & 462.20 & 508.80 \\
\hline 2011 & 10.295 & 48.245 & 2011 & 528.83 & 572.74 & 2011 & 509.76 & 584.48 \\
\hline 2012 & 10.897 & 50.23 & 2012 & 500.36 & 550.93 & 2012 & 481.70 & 563.58 \\
\hline 2013 & 11.68 & 50.8 & 2013 & 524.23 & 584.64 & 2013 & 506.69 & 597.82 \\
\hline 2014 & 11.495 & 51.874 & 2014 & 545.39 & 580.25 & 2014 & 525.24 & 592.53 \\
\hline 2015 & 11.743 & 53.009 & 2015 & 477.58 & 503.65 & 2015 & 460.25 & 508.19 \\
\hline 2016 & 11.267 & 53.371 & 2016 & 472.03 & 515.74 & 2016 & 453.44 & 519.29 \\
\hline 2017 & 10.964 & 54.201 & 2017 & 526.22 & 540.54 & 2017 & 504.58 & 548.71 \\
\hline 2018 & 11.284 & 54.645 & 2018 & 585.66 & 556.09 & 2018 & 560.91 & 564.72 \\
\hline 2019 & 12.164 & 56.391 & 2019 & 570.78 & 551.03 & 2019 & 546.84 & 559.08 \\
\hline 2020 & 11.69 & 59.48 & 2020 & 570.04 & 566.25 & 2020 & 531.51 & 570.64 \\
\hline 2021 & 12.34 & 61.05 & 2021 & 587.16 & 576.51 & 2021 & 548.44 & 584.42 \\
\hline 2022 & 12.61 & 61.66 & 2022 & 604.27 & 586.76 & 2022 & 565.37 & 598.20 \\
\hline
\end{tabular}

Source: Own elaboration on the basis of EUROSTAT and World Bank data.

An increasing tendency has been observed in both countries but it is worth it to underline that the share is much higher in Sweden than in Poland. Moreover, the increase 
in Poland is not regular and some decreases are noticed (within the period of 2015 to 2020). The correlation between the use of RES, GDP, and GNI show the well-developed country is more advanced in using RES. The forecasts are also optimistic because the use of RES is increasing but the pace of the increase is higher in Sweden again.

Figure 3 presents the correlation between GDP, GNI, and RES for Poland and Sweden within the period of 1991-2022 (with extrapolation).

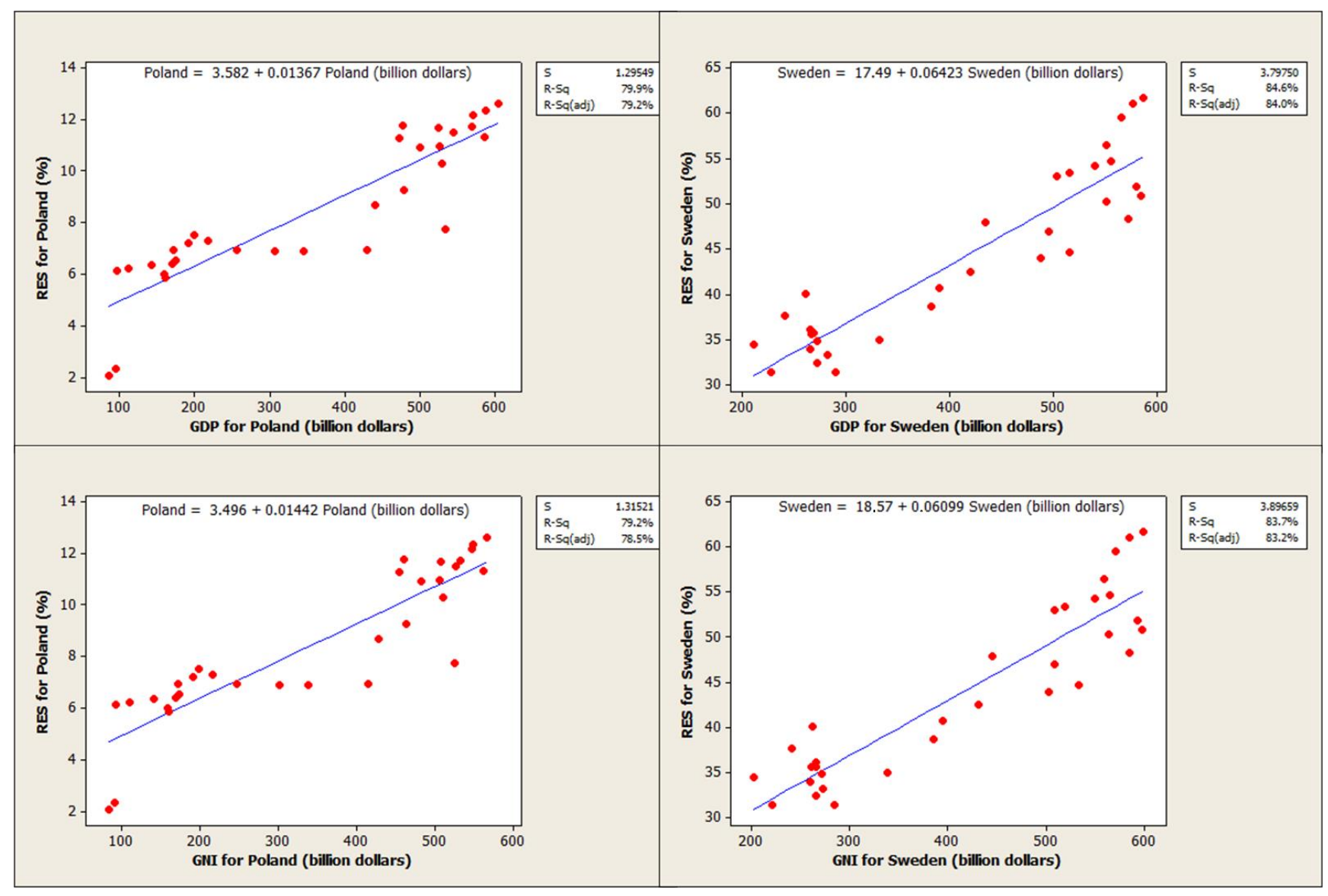

Figure 3. Correlations between GDP, GNI (in billion USD), and RES for Poland and Sweden.

Correlations between GDP, GNI, and RES for both Poland and Sweden are very high. Relations between RES and GDP for Poland and Sweden (79.9\% and $84.6 \%$, respectively) indicate a good fit between the analyzed variables. The standard deviation for Poland and Sweden $(S=1.29549$ and $S=3.79750$, respectively) shows that GDP values are not dispersed widely around its average. Correlations between RES and GNI for Poland and Sweden (79.2\% and $83.7 \%$ respectively) also point at an accurate fit between the variables. The GNI values for Poland and Sweden are not so dispersed around its average $(\mathrm{S}=1.31521$ and $\mathrm{S}=3.89659$, respectively), as is shown in Figure 3.

Figure 4 depicts high values of the coefficient of determination $(\mathrm{R}-\mathrm{Sq}=84.3 \%)$, which means that the model provides a good fit and the authors of the paper can have confidence in its ability to predict the future share of RES for both analyzed countries. It determines the independent variable (RES), which means that the data fit well the regression model. The standard deviation (S) equals 1.14516, which means that the RES values are not dispersed widely around its average. Nevertheless, if R-Sq is high, there is still ambiguity in how large the percentage needs to be in order to be considered a good fit. Based on the statistics generated, linear regression is still an optimal forecasting method. Viewed in terms of prediction, the estimated trend is increasing because a part of the extrapolated series give 
the clearest indication of the future movements in the series. Thereupon, the forecast presented in Figure 4 estimates the best fit regression line for the given data.

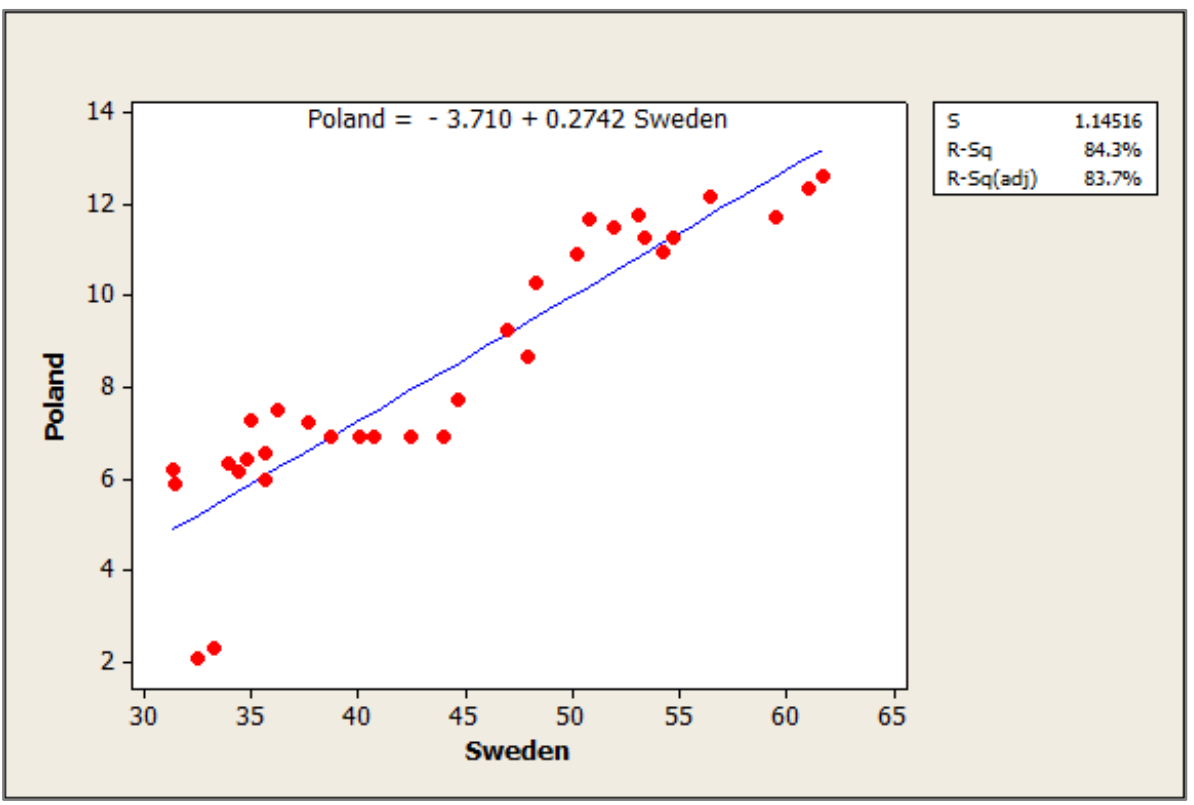

Figure 4. Poland's and Sweden's coefficient of RES.

\subsection{Regression Model Based on Variable Y (Renewable) and Variable X (GDP) for Poland}

The dependent $Y$ variable (RES) is the share of renewable energy sources in gross energy consumption. In turn, the variables GDP and GNI are the explanatory $\mathrm{X}$ variables. The variables are opposite-GDP and GNI are dependent variables, whereas RES is an explanatory variable. The results of modeling the GDP influencing the share of RES in gross marginal energy consumption in Poland within 1991-2022 are presented in Table 2.

Table 2. Results of modeling the share of renewable energy sources in gross marginal energy consumption in Poland in 1991-2022 using a linear econometric model of one variable.

\begin{tabular}{|c|c|c|c|c|}
\hline \multirow{2}{*}{$\mathrm{N}=32$} & \multicolumn{4}{|c|}{$\begin{array}{l}R=0.89383973, R^{2}=0.79894947, \text { Corr. } R^{2}=0.79224778 \\
F(1.30)=119.22, p<0.00000, \text { Std Error of Estim. } 1.2892\end{array}$} \\
\hline & Coefficients & Standard Error & $\mathrm{t}$-Stat & $p$ Value \\
\hline Absolute term & 3.589947 & 0.494204 & 7.26410 & 0.00000004 \\
\hline $\operatorname{GDP}\left(\mathrm{X}_{1}\right)$ & 0.013618 & 0.001247 & 10.91862 & 0.00000000 \\
\hline
\end{tabular}

The model of the share of renewable energy sources in gross marginal energy consumption in Poland (GDP) is outlined in Equation (1):

$$
\hat{Y}_{t}=3.58995+0.013618 X_{1}
$$

The estimated model shows that if the $\mathrm{X}_{1}$ variable denoting the amount of GDP expressed in USD billion increases by one whole unit (USD 1 billion), the share of renewable energy sources in gross marginal energy consumption will also increase by $13.618 \%$. The intercept is the data that determines the magnitude of the value of $Y$ for the period preceding the analyzed phenomenon. It is a constant and independent value, and its positive value, in this case, means that with each successive period, the variable $Y$ will increase.

The estimated econometric model is relatively well-adjusted to the empirical data and reflects the changes of this phenomenon over time in $79.89 \%$. It is evidenced by the value of the $R^{2}$ coefficient $=0.7989$. The actual values of the share of renewable energy sources in the gross marginal energy consumption in subsequent years deviate from the estimated model 
by $1.2892 \%$ on average. On the other hand, the residual deviation, speaking about the average deviation of the theoretical values from the arithmetic mean of empirical values, is $\mathrm{S}_{\mathrm{e}}=1.299 \%$.

The last phenomenon presented is the importance of the structural parameters. The hypotheses can be presented as follows: the hypothesis $\mathrm{H}_{0}$ applies to the situation where it $=0$, and the parameter is statistically insignificant. On the other hand, there is the $\mathrm{H}_{1}$ hypothesis, where it $\neq 0$ and the parameter is statistically significant. Satisfying the $p$-value inequality implies the rejection of the $\mathrm{H}_{0}$ hypothesis in favor of the $\mathrm{H}_{1}$ alternative. In the tested example, $\alpha=0.05$, and the value $p$, as shown in Table 2 , is a minimal value, and its first number is at the 8 th decimal place. This relationship shows that the $\mathrm{H}_{0}$ hypothesis was rejected, favoring the $\mathrm{H}_{1}$ alternative, which means that the structural parameter is statistically significant. The variable $\mathrm{X}_{1}$ has a significant impact on the dependent variable $Y$.

Another model that concerns the data was developed for Poland, as outlined in Table 3. However, as the previous GDP was used, this section focuses on Gross National Income, as the $\mathrm{X}_{1}$ variable influences the share of renewable energy sources in the gross marginal energy consumption as the $\mathrm{Y}$ variable.

Table 3. Results of modeling the share of renewable energy sources in gross marginal energy consumption in Poland in 1991-2022 using a linear econometric model of one variable.

\begin{tabular}{|c|c|c|c|c|}
\hline \multirow{2}{*}{$N=32$} & \multicolumn{4}{|c|}{$\begin{array}{l}R=0.89027206, R^{2}=0.79258435, \text { Corr. } R^{2}=0.78567049 \\
F(1.30)=114.64, p<0.00000, \text { Std Error of Estim. } 1.3094\end{array}$} \\
\hline & Coefficients & Standard Error & t-Stat & $p$ Value \\
\hline Absolute term & 3.504782 & 0.510628 & 6.86367 & 0.00000013 \\
\hline GNI $\left(X_{1}\right)$ & 0.014364 & 0.001342 & 10.70687 & 0.00000000 \\
\hline
\end{tabular}

The estimated model shows that if the $X_{1}$ variable denoting the value of GNI expressed in USD billion increases by one whole unit (USD 1 billion), the share of renewable energy sources in the gross marginal energy consumption will also increase by $14.36 \%$. The estimated econometric model is exceptionally well suited to the empirical data and reflects the changes in this phenomenon over time to be $79.26 \%$. In this case, the $\mathrm{H}_{0}$ hypothesis also was rejected in favor of the alternative hypothesis $\mathrm{H}_{1}$, which means that the structural parameter is statistically significant. The variable $X_{1}$ has a significant impact on the dependent variable Y. Completing the regression analysis, the model of the share of renewable energy sources in the gross marginal energy consumption in Poland (GNI) is presented below in Equation (2):

$$
\hat{Y}_{t}=3.5048+0.01436 X_{1}
$$

\subsection{Regression Model Based on Variable Y (Renewable) and Variable X (GDP) for Sweden}

The following two regression models were developed for Sweden. To create the current model, Sweden's GDP was used as variable $X_{1}$, influencing the share of renewable energy sources in the gross marginal energy consumption as variable Y (Table 4).

Table 4. Results of modeling the share of renewable energy sources in gross marginal energy consumption in Sweden in 1991-2022 using a linear econometric model of one variable.

\begin{tabular}{|c|c|c|c|c|}
\hline \multirow{2}{*}{$\mathbf{N}=32$} & \multicolumn{4}{|c|}{$\begin{array}{l}\mathrm{R}=0.91952560, \mathrm{R}^{2}=0.84552732, \text { Corr. } \mathrm{R}^{2}=0.84037824 \\
\mathrm{~F}(1.30)=164.21, p<0.00000, \text { Std Error of Estim. } 3.7974\end{array}$} \\
\hline & Coefficients & Standard Error & t-Stat & $p$ Value \\
\hline Absolute term & 17.48746 & 2.183803 & 8.00780 & 0.00000001 \\
\hline $\operatorname{GDP}\left(X_{1}\right)$ & 0.06423 & 0.005012 & 12.81441 & 0.00000000 \\
\hline
\end{tabular}


The estimated model shows that if the variable $X_{1}$, denoting the amount of GDP expressed in USD billion, increases by one whole unit (USD 1 billion), the share of renewable energy sources in gross marginal energy consumption in Sweden would also increase by $64.2 \%$. Such a considerable increase is no longer possible in this country due to the current share of renewable energy sources. Still, it shows how quickly the share of renewable energy in the gross marginal energy consumption grew there. The estimated econometric model is well suited to the empirical data and reflects $84.55 \%$ of the changes in this phenomenon over time. It is evidenced by the value of the coefficient $R^{2}=0.8455$. The actual values of the share of renewable energy sources in the gross marginal energy consumption in the following years deviate from the estimated model by $3.797 \%$ on average. In turn, the residual deviation, indicating the average deviation of the theoretical values from the arithmetic mean of empirical values, is $S_{e}=3.799 \%$.

The last phenomenon presented is the importance of the structural parameters. The $\mathrm{H}_{0}$ hypothesis was rejected in favor of the alternative $\mathrm{H}_{1}$ hypothesis, which means that the structural parameter is statistically significant. The variable $X_{1}$ has a significant impact on the dependent variable Y. Completing the regression analysis, the model of the share of renewable energy sources in the gross marginal energy consumption in Sweden (GDP) is presented below:

$$
\hat{Y} t=17.4875+0.06423 X_{1}
$$

The second of the Swedish regression models was created using the GNI of Sweden as the variable $X_{1}$, influencing the share of renewable energy sources in the gross marginal energy consumption as variable $\mathrm{Y}$ (Table 5).

Table 5. Results of modeling the share of renewable energy sources in gross marginal energy consumption in Sweden in 1991-2022 using a linear econometric model of one variable.

\begin{tabular}{ccccc}
\hline & \multicolumn{3}{c}{$\mathbf{R}=\mathbf{0 . 9 1 5 0 7 4 0 4 ,} \mathbf{R}^{\mathbf{2}}=\mathbf{0 . 8 3 7 3 6 0 5 1}$, Corr. $\mathbf{R}^{\mathbf{2}}=\mathbf{0 . 8 3 1 9 3 9 1 9}$} \\
$\mathbf{N}=\mathbf{3 2}$ & \multicolumn{2}{c}{$\mathbf{F}(\mathbf{1 . 3 0})=\mathbf{1 5 4 . 4 6}, \boldsymbol{p}<\mathbf{0 . 0 0 0 0 0 ,}$ Std Error of Estim. 3.8965 } \\
\cline { 2 - 5 } & Coefficients & Standard Error & t-Stat & $p$ Value \\
\hline Absolute term & 18.57016 & 2.167887 & 8.56602 & 0.00000001 \\
GNI $\left(X_{1}\right)$ & 0.06099 & 0.004908 & 12.42807 & 0.00000000 \\
\hline
\end{tabular}

The estimated model shows that if the $X_{1}$ variable denoting the value of GNI expressed in a billion USD increases by one whole unit (USD 1 billion), the share of renewable energy sources in gross marginal energy consumption in Sweden will also increase by $61 \%$. The estimated econometric model is well suited to the empirical data and reflects $83.74 \%$ of the changes in this phenomenon over time. The last phenomenon presented shows the importance of the structural parameter $\alpha_{i}$. In the tested example, $\alpha=0.05$, the $p$ value, as shown in Table 5, is a minimal value, and its first number is at the 9th decimal place. This dependence shows that the $\mathrm{H}_{0}$ hypothesis was rejected, favoring the $\mathrm{H} 1$ alternative hypothesis, which means that the structural parameter is statistically significant. The variable $\mathrm{X}_{1}$ has a significant impact on the dependent variable $\mathrm{Y}$. Completing the regression analysis, the model of the share of renewable energy sources in gross marginal energy consumption in Sweden (GNI) is presented below:

$$
\hat{Y}_{t}=18.5702+0.06099 X_{1}
$$

\subsection{Regression Model Based on GDP (Variable Y) and Renewable (Variable $X_{1}$ ) for Poland and Sweden}

The last analyzed dependence is the opposite situation to the previous two items. The current model was created using the share of renewable energy sources in the gross marginal energy consumption as the $X_{1}$ variable influencing the size of the Gross Domestic Product as the dependent variable Y. The model illustrating this situation in both Poland 
and Sweden is detailed below. In the analyzed example, all the necessary data for Poland is presented in Table 6 and for Sweden in Table 7.

Table 6. The results of modeling the Gross Domestic Product in Poland in 1991-2022 using a linear econometric model of one variable.

\begin{tabular}{|c|c|c|c|c|}
\hline \multirow{2}{*}{$N=32$} & \multicolumn{4}{|c|}{$\begin{array}{l}R=0.89383973, R^{2}=0.79894947, \text { Corr. } R^{2}=0.79224778 \\
F(1.30)=119.22, p<0.00000, \text { Std Error of Estim. } 84.617\end{array}$} \\
\hline & Coefficients & Standard Error & t-Stat & $p$ Value \\
\hline Absolute term & -139.929 & 47.43734 & -2.94976 & 0.006114 \\
\hline RES share $\left(X_{1}\right)$ & 58.669 & 5.37327 & 10.91862 & 0.000000 \\
\hline
\end{tabular}

Table 7. The results of modeling the Gross Domestic Product in Sweden in 1991-2022 using a linear econometric model of one variable.

\begin{tabular}{|c|c|c|c|c|}
\hline \multirow{2}{*}{$N=32$} & \multicolumn{4}{|c|}{$\begin{array}{l}R=0.91952560, R^{2}=0.84552732, \text { Corr. } R^{2}=0.84037824 \\
F(1.30)=164.21, p<0.00000, \text { Std Error of Estim. } 54.363\end{array}$} \\
\hline & Coefficients & Standard Error & t-Stat & $p$ Value \\
\hline Absolute term & -166.160 & 46.32738 & -3.58665 & 0.001172 \\
\hline RES share $\left(X_{1}\right)$ & 13.164 & 1.02727 & 12.81441 & 0.000000 \\
\hline
\end{tabular}

The estimated model shows that if the variable $X_{1}$, denoting the share of renewable energy sources in Poland's gross marginal energy consumption expressed in \%, increases by one whole unit (1\%), GDP will increase by USD 58.67 billion. The estimated econometric model is exceptionally well suited to the empirical data, and at $79.89 \%$, it reflects the change in this phenomenon over time as in the inverse case where GDP was the variable Y. On the other hand, the residual deviation, representing the average deviation of the theoretical values from the arithmetic mean of empirical values, was Se = USD 84.62 billion. The last phenomenon presented is the importance of the structural parameter $\alpha_{i}$. The $\mathrm{H}_{0}$ hypothesis was rejected in favor of the alternative $\mathrm{H} 1$ hypothesis, which means that the structural parameter is statistically significant. The variable $X_{1}$ has a significant impact on the dependent variable Y. Complementing the regression analysis below, the model of the Gross Domestic Product in Poland, depending on the share of renewable energy sources, is presented in the gross marginal energy consumption (see Equation (5)):

$$
\hat{Y}_{t}=-139.93+58.669 X_{1}
$$

In turn, the situation in Sweden is mentioned in Table 7.

The estimated model shows that if the variable $X_{1}$ representing the share of renewable energy sources in Sweden's gross marginal energy consumption expressed in \% increases by one whole unit (1\%), GDP would increase by USD 13.16 billion. The estimated econometric model is exceptionally well suited to the empirical data and at $84.55 \%$ reflects the change of this phenomenon over time as in the inverse case where GDP was the variable Y. The $\mathrm{H}_{0}$ hypothesis was rejected in favor of the $\mathrm{H} 1$ alternative hypothesis, which means that the structural parameter is statistically significant and the variable $X_{1}$ has a significant impact on the dependent variable Y. Completing the regression analysis, the model of Gross Domestic Product in Sweden, depending on the share of renewable energy sources in gross marginal energy consumption, is formulated using Equation (6):

$$
\hat{Y}_{t}=-166.16+13.164 X_{1}
$$


To sum up, positive correlation between GDP and GNI variables (which is statistically significant) for Sweden ( $84.6 \%$ and $83.7 \%$, respectively) and Poland $(79.9 \%$ and $79.2 \%$, respectively) influences the use of renewable energy sources. The findings of the study reveal the importance of RES use in the leading countries but simultaneously the paper points that the risk of recession is higher in these economies in comparison to less-income countries.

\section{Discussion}

The results of this research fill in the research gap concerning the renewables share in highly developed and developed countries. The comparative analysis made it possible to compare the fundamental indicators of economic growth (GDP, GNI) with the use of a regression model. The research conducted by the authors of the paper confirm the need of disseminating the knowledge about RES and its use by different economies. The current state of research concerning the problem still seems to be verified in order to provide evidence on the importance of the problem and correlations between the analyzed coefficients. The research conducted by the authors partially confirm the positive and dynamic impact of renewables on the GDP and GNI of the countries. Additionally, economic recession can constitute a danger for well-developed countries [33]. The higher economic growth caused by the use of renewables is possible but in time the risk of a greater recession is much more possible than in other countries simultaneously.

Answering the first research question, there is a positive relationship between the share of RES in gross marginal energy consumption and economic growth. The higher the economic growth, the more often renewables are used in the countries because they play a significant role in building the economic growth of their economies. In the situation when the GDP and GNI are lower, renewable energy sources are less often used by the government of the country. Another relationship (second question) was to investigate whether the variables interact with each other in the regression model. A critical issue that has been concluded from the analysis of the regression model used in the research is that the more RES-addicted the economy, the worse the situation of the country (in case of any economic crisis and fluctuations). In the situation of economic recession, the country feels the effects of the RES share decrease more often than other less RES-addicted countries. It can be confirmed by the research because it was observed in the results and correlations. Because the study is an attempt to disseminate effects on the structure of the energy sector data, the regression models are presented in a comparative form in Table 8. The bold text indicates the most favorable values. For example, the model for Poland, where the dependent $Y$ variable (RES) distinguished the share of renewable energy sources in gross marginal energy consumption, was compared using the explanatory variable. Concerning $\operatorname{GDP}\left(X_{1}\right)$, the model was better adjusted to empirical data, and the reflection of the change of this phenomenon overtime was more favorable. The situation with the standard error of estimation was similarly more favorable because the value was lower than when explaining RES using GNI, which meant that the actual values deviated from the estimated model. On the other hand, in the case of estimating the $Y$ variable with the GNI variable $\left(X_{1}\right)$, there was a higher increase in the $Y$ variable when the $X_{1}$ variable increased by one unit (USD billion). However, based on available information, the regression model exhibiting the modeling of the share of renewable energy sources in gross marginal energy consumption in Poland in 1991-2022, with the use of the linear econometric model, is accurately estimated by the Gross Domestic Product due to the lower error. 
Table 8. Summary of the regression models.

\begin{tabular}{|c|c|c|c|c|c|c|}
\hline \multirow[b]{2}{*}{ Summary } & \multicolumn{6}{|c|}{ Poland } \\
\hline & $\begin{array}{c}\text { Increase of the } X_{1} \\
\text { Variable by One Unit } \\
\text { Causes an Increase in the } \\
\text { Dependent Variable by: }\end{array}$ & $\mathbf{R}^{2}$ & $\begin{array}{l}\text { Standard Error } \\
\text { of Estimation: }\end{array}$ & $\begin{array}{l}\text { Significance of } \\
\text { the F Statistics }\end{array}$ & $\begin{array}{l}\text { The Importance } \\
\text { of Structural } \\
\text { Parameters }\end{array}$ & Correlation \\
\hline $\operatorname{RES}(\mathrm{Y}), \operatorname{GDP}\left(\mathrm{X}_{1}\right)$ & $13.618 \%$ & 0.798949 & $1.2892 \%$ & $5.86 \times 10^{-12}$ & 0.00000004 & 0.8938 \\
\hline $\operatorname{RES}(\mathrm{Y}), \mathrm{GNI}\left(\mathrm{X}_{1}\right)$ & $14.364 \%$ & 0.792584 & $1.3094 \%$ & $9.11 \times 10^{-12}$ & 0.00000013 & 0.8903 \\
\hline GDP $(Y), \operatorname{RES}\left(\mathrm{X}_{1}\right)$ & 58.669 billion USD & 0.798949 & $\begin{array}{l}84.617 \text { billion } \\
\text { USD }\end{array}$ & $5.86 \times 10^{-12}$ & 0.00611400 & 0.8938 \\
\hline GNI $(\mathrm{Y}), \operatorname{RES}\left(\mathrm{X}_{1}\right)$ & 55.179 billion USD & 0.792584 & $\begin{array}{l}82.763 \text { billion } \\
\text { USD }\end{array}$ & $9.11 \times 10^{-12}$ & 0.01117993 & 0.8903 \\
\hline \multirow[b]{2}{*}{ Summary } & \multicolumn{6}{|c|}{ Sweden } \\
\hline & $\begin{array}{c}\text { Increase of the } X_{1} \\
\text { Variable by One Unit } \\
\text { Causes an Increase in the } \\
\text { Dependent Variable by: }\end{array}$ & $\mathbf{R}^{2}$ & $\begin{array}{l}\text { Standard Error } \\
\text { of Estimation: }\end{array}$ & $\begin{array}{l}\text { Significance of } \\
\text { the F Statistics }\end{array}$ & $\begin{array}{l}\text { The Importance } \\
\text { of Structural } \\
\text { Parameters }\end{array}$ & Correlation \\
\hline $\operatorname{RES}(\mathrm{Y}), \mathrm{GDP}\left(\mathrm{X}_{1}\right)$ & $64.23 \%$ & 0.845527 & $3.7974 \%$ & $2.69 \times 10^{-13}$ & 0.00000001 & 0.9195 \\
\hline $\operatorname{RES}(\mathrm{Y}), \mathrm{GNI}\left(\mathrm{X}_{1}\right)$ & $60.99 \%$ & 0.837360 & $3.8965 \%$ & $2.31 \times 10^{-13}$ & 0.000000001 & 0.9151 \\
\hline GDP $(Y), \operatorname{RES}\left(X_{1}\right)$ & 13.164 billion USD & 0.845527 & $\begin{array}{l}54.363 \text { billion } \\
\text { USD }\end{array}$ & $2.69 \times 10^{-13}$ & 0.001172 & 0.9195 \\
\hline GNI $(Y), \operatorname{RES}\left(\mathrm{X}_{1}\right)$ & 13.729 billion USD & 0.837360 & $\begin{array}{l}58.897 \text { billion } \\
\text { USD }\end{array}$ & $2.31 \times 10^{-13}$ & 0.00075493 & 0.9151 \\
\hline
\end{tabular}

Source: Own study based on EUROSTAT and World Bank data.

Figure 5 depicts the comparison in trend analyses for both countries in terms of the economic indicators, showing their tendency to grow in the next few years. The prognosis of GDP and GNI fluctuations are positive concerning both countries. The regression model is more accurately illustrated when the dependent variable is the GDP indicator than the GNI. The model (linear econometric model of one variable) represents the creation of economic growth and development in Poland within 1991-2022 using the share of RES in the gross marginal energy consumption. The regression that models the share of renewable energy sources in the gross marginal energy consumption in Sweden in 1991-2022 through the application of a linear econometric model of one variable is also better estimated by the GDP. It is argued that there is a minor error and an adjustment of the model to the data, but also the fact that an increase in GDP by one unit (USD billion) causes a greater increase in the share of RES compared to GNI The regression model (linear econometric model of one variable) presenting the creation of economic growth and development in Sweden, with the use of renewable energy sources in the gross marginal energy consumption, is better illustrated when the dependent variable is GDP than GNI. However, despite the above selection between GDP and GNI, both variables affect the RES variable to a similar extent, and RES describe both similarly. The RES variable is statistically significant for the regression model. The positive correlation between the share of renewable energy sources in the gross final energy consumption and GDP in Poland was 0.89384, whereas in Sweden the correlation equaled 0.91953. Considering the correlation between the share of renewable energy sources in the gross final energy consumption and GNI, the research shown that it was a positive correlation in Poland (0.89027) and in Sweden (0.91507). The variable determining the share of renewable energy sources significantly influences the shaping of the variable denoting economic growth (GDP and GNI) in Poland and Sweden. Considering the lower ex-ante error, a better fit is characteristic for the model with the GDP variable. The variable determining economic growth (GDP and GNI) significantly influences the shape of the variable determining the share of renewable energy sources in Poland and Sweden. These results are consistent with the data presented in the Global Renewables Outlook report, which emphasizes that the increase in expenditure on "green" transformation leads to faster global GDP growth—by $2.4 \%$ more than with the current 
plans (IRENA 2020). Investments in renewable energy sources should increase economic growth and the number of jobs.

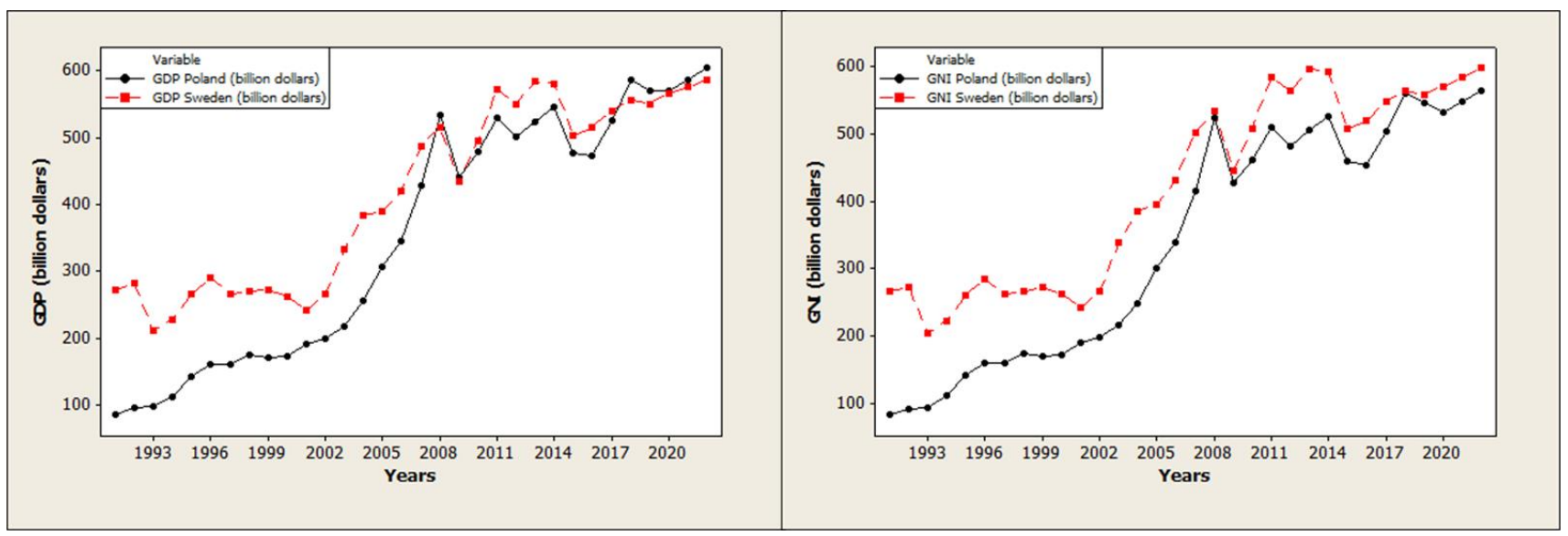

Figure 5. Comparison of GDP vs. GNI for Poland and Sweden between 1991 and 2022.

The analysis of linear regression made it possible to predict the value of one variable (GDP, GNI) on the basis of the other variable (RES). Thanks to this method, the analyzed countries may make optimal decisions concerning RES use and how it influences their economic growth. Moreover, thanks to data analysis and with the use of a linear regression model, the decision-makers of the countries now have an in-depth analysis and presentation of the new models and relations between coefficients.

\section{Energy Policy Implication and Future Agenda for Economic Growth}

The statistical differences between countries should be on display by the governments' decision-makers to mainstream this into energy policy within the EU. It should help align these differences in economic values between less-income Polish and high-income Swedish economies. Moreover, those issues will be most significant for small and medium enterprises, which account for the generation for $29 \%$ of the added values in Poland [65] versus more than $61 \%$ in the Swedish "non-financial business economy" [66]. The consequences of lack of coherence and unified EU energy policy leads to a gap in the relevant literature and prompts to examine forecasting models or tools for applying energy policy in practice. A discussion on energy policy research cannot be separated from the macroeconomic determinants. Therefore, research must be addressed to the factors of unified energy policy to set energy targets for European countries, and then make interventions in order to meet the goals and targets that influence the nation's energy demand. In this context, it would be a crucial agenda of the EU governments by restructuring the content of the current, incoherent energy policy. Element such as economic impact of energy prices and cost-effective investment in RES should be supported adequately by politicians and decision-makers, thereby becoming competitive [67].

In line with the abovementioned finding, some energy policy implications can be recommended for managing the RES energy demand:

- Energy efficiency improvements in the EU countries by implementation of technological innovations. Thanks to that, a balance in the macroeconomic factors between these countries could be maintained.

- Supportive initiatives to promote the reduction dependency on fossil fuels, especially in Poland, and permanent diversification its energy mix by augmenting renewable energy resources.

- Fiscal and tax policies make them particularly essential to examine the negative or positive impact of macroeconomic factors.

- $\quad$ Research models and methods towards facilitating management and evaluation should be able to use existing energy data to generate statistical reports available 
for the public institutions. They might be necessary to analyze energy-related trends and provide sufficient indicators for newest technological initiatives.

A transformation into sustainable energy and infrastructure in the post-COVID-19 time through different models is needed in the next few years to provide sustainable economies while ensuring equitable energy planning for economic growth [68].

\section{Conclusions}

The goal of the study was achieved by depicting the positive correlations between energy-related variables on the level of economic growth in Poland and Sweden. Economic growth and development as well as the share of renewable energy sources in gross marginal energy consumption [69] are the variables between which mutual interaction occurs both these countries. The positive correlations observed between these variables were characterized by the fact that the increase in gross marginal energy consumption contributes to the increase in economic growth. The share of RES could be increased drastically by taking actions to accelerate the economic growth in less-developed countries and promoting national initiatives. The calculation of correlations revealed that in Sweden there was the largest gap ( $0.44 \%)$ between its GDP and GNI compared to Poland $(0.35 \%)$. In general, in Sweden the impact of RES on GDP is higher by about $2.57 \%$ in comparison to Poland, and greater by $2.48 \%$ given the RES-GNI analysis.

The results confirm also that the long-term perspective of the economic growth of those developed countries in terms of GDP depends on energy consumption from renewables. The results achieved do not support the research done in [38]. Therefore, developing countries are making more efforts to replace fossil fuels and reduce their dependence by investing in renewable energy resources [6]. The pandemic could change the values of the economic variables only temporarily and in the long run shift to focus on the growth relationship (energy-GDP and energy-GNI). Therefore, the pandemic might result in a significant decrease in all the parameters. The study seems to be unique through mapping of the correlation effects on the structure of the energy sector across the last 20 years, shifting from a traditional fossil-based economy into a renewables-based economy. It, in turn, makes this research different from other studies and fill a gap in the present literature and statistical reports. This paper provides new insight for further research on other countries that are differentiated in terms of economic growth, income, and use of RES. The in-depth analysis could focus on renewable energy sources that impact not only on GDP and GNI but also on other economic quantitative (Net National Income-NNI, inflation rate, GDP per capita, budget deficit, etc.) and qualitative (Human Development Index-HDI, Human Poverty Index-HPI, extent of investments, etc.) indicators.

Moreover, this paper highlights the fundamentals for further research in the area of using renewable energy sources in all European Union countries, taking the abovementioned economic indicators into account.

Author Contributions: Conceptualization, B.Ś., P.Ż. and A.K.; methodology, B.Ś., P.Ż. and A.K.; software, A.K. and P.Ż.; validation, B.Ś., P.Ż., A.K. and A.N.; formal analysis, B.Ś., P.Ż., A.K. and A.N.; investigation, P.Ż., A.K., A.N. and M.G.; resources, B.Ś., P.Ż., A.K., A.N. and M.G.; data curation, B.Ś., P.Ż., A.K. and A.N.; writing—original draft preparation, B.Ś., A.K., P.Ż. and A.N.; writingreview and editing, P.Ż. and A.K.; visualization, P.Ż. and A.K.; supervision, P.Ż. and A.K.; project administration, P.Ż., A.K., A.N. and M.G.; funding acquisition, B.Ś., P.Ż., A.K., A.N. and M.G. All authors have read and agreed to the published version of the manuscript.

Funding: This research received no external funding.

Institutional Review Board Statement: Not applicable.

Informed Consent Statement: Not applicable.

Data Availability Statement: The study did not report any data.

Conflicts of Interest: The authors declare no conflict of interest. 


\section{References}

1. Yang, L.; Wang, X.-C.; Dai, M.; Chen, B.; Qiao, Y.; Deng, H.; Zhang, D.; Zhang, Y.; Almeida, C.; Chou, A.; et al. Shifting from Fossil-Based Economy to Bio-Based Economy: Status Quo, Challenges, and Prospects. Energy 2021, 228, 120533. [CrossRef]

2. IRENA. Renewable Power Generation Costs in 2019; IRENA: Abu Dhabi, United Arab Emirates, 2020.

3. Shabbir, M.S.; Muhammad, I. The Dynamic Impact of Foreign Portfolio Investment on Stock Prices in Pakistan. Transnatl. Corp. Rev. 2019, 11, 166-178. [CrossRef]

4. Shabbir, M.S.; Wisdom, O. The Relationship between Corporate Social Responsibility, Environmental Investments and Financial Performance: Evidence from Manufacturing Companies. Environ. Sci. Pollut. Res. 2020, 27, 39946-39957. [CrossRef]

5. Wang, Z.; Danish; Zhang, B.; Wang, B. Renewable Energy Consumption, Economic Growth and Human Development Index in Pakistan: Evidence Form Simultaneous Equation Model. J. Clean. Prod. 2018, 184, 1081-1090. [CrossRef]

6. Ozcan, B. Renewable Energy Consumption-Economic Growth Nexus in Emerging Countries: A Bootstrap Panel Causality Test. Renew. Sustain. Energy Rev. 2019, 104, 30-37. [CrossRef]

7. Destek, M.A.; Sinha, A. Renewable, Non-Renewable Energy Consumption, Economic Growth, Trade Openness and Ecological Footprint: Evidence from Organisation for Economic Co-Operation and Development Countries. J. Clean. Prod. 2020, $242,118537$. [CrossRef]

8. Nasreen, S.; Anwar, S.; Ozturk, I. Financial Stability, Energy Consumption and Environmental Quality: Evidence from South Asian Economies. Renew. Sustain. Energy Rev. 2017, 67, 1105-1122. [CrossRef]

9. Muhammad, I.; Shabbir, M.; Saleem, S.; Bilal, K.; Ulucak, R. Nexus between Willingness to Pay for Renewable Energy Sources: Evidence from Turkey. Environ. Sci. Pollut. Res. Int. 2021, 28, 2972-2986. [CrossRef]

10. Khuong, N.V.; Shabbir, M.S.; Sial, M.S.; Khanh, T.H.T. Does Informal Economy Impede Economic Growth? Evidence from an Emerging Economy. J. Sustain. Financ. Invest. 2021, 11, 103-122. [CrossRef]

11. Murshed, M.; Alam, M. An Estimation of the Macroeconomic Determinants Total, Renewable and Non-Renewable Energy Demands in Bangladesh: The Role of Technological Innovations. Environ. Sci. Pollut. Res. 2021, 28, 30176-30196. [CrossRef]

12. Aslan, A.; Öcal, O. The Role of Renewable Energy Consumption in Economic Growth: Evidence from Asymmetric Causality. Renew. Sustain. Energy Rev. 2016, 60, 953-959. [CrossRef]

13. Apergis, N.; Chang, T.; Gupta, R.; Ziramba, E. Hydroelectricity Consumption and Economic Growth Nexus: Evidence from a Panel of Ten Largest Hydroelectricity Consumers. Renew. Sustain. Energy Rev. 2016, 62, 318-325. [CrossRef]

14. Bhattacharya, M.; Paramati, S.R.; Ozturk, I.; Bhattacharya, S. The Effect of Renewable Energy Consumption on Economic Growth: Evidence from Top 38 Countries. Appl. Energy 2016, 162, 733-741. [CrossRef]

15. Bildirici, M.E.; Gökmenoğlu, S.M. Environmental Pollution, Hydropower Energy Consumption and Economic Growth: Evidence from G7 Countries. Renew. Sustain. Energy Rev. 2017, 75, 68-85. [CrossRef]

16. Armeanu, D.Ş.; Vintilă, G.; Gherghina, Ş.C. Does Renewable Energy Drive Sustainable Economic Growth? Multivariate Panel Data Evidence for EU-28 Countries. Energies 2017, 10, 381. [CrossRef]

17. Bilgili, F.; Ozturk, I. Biomass Energy and Economic Growth Nexus in G7 Countries: Evidence from Dynamic Panel Data. Renew. Sustain. Energy Rev. 2015, 49, 132-138. [CrossRef]

18. Pegkas, P. The Impact of Renewable and Non-Renewable Energy Consumption on Economic Growth: The Case of Greece. Int. J. Sustain. Energy 2020, 39, 380-395. [CrossRef]

19. Polish Economic Institute. Poland ranks 32nd in the Responsible Development Index. In Polish: Polska na 32. Miejscu w Indeksie Odpowiedzialnego Rozwoju. Available online: https://www.thefirstnews.com/article/poland-ranks-32nd-in-responsibledevelopment-index---economic-institute-15743 (accessed on 20 December 2021).

20. Sachs, J.; Kroll, C.; Lafortune, G.; Fuller, G. The Sustainable Development Goals and COVID-19: Includes the SDG Index and Dashboards; Sustainable Development Report; Cambridge University Press: Cambridge, UK, 2021; ISBN 978-1-108-83420-9.

21. Muñoz-La Rivera, F.; Hermosilla, P.; Delgadillo, J.; Echeverría, D. The Sustainable Development Goals (SDGs) as a Basis for Innovation Skills for Engineers in the Industry 4.0 Context. Sustainability 2020, 12, 6622. [CrossRef]

22. Ben Jebli, M.; Ben Youssef, S. The Environmental Kuznets Curve, Economic Growth, Renewable and Non-Renewable Energy, and Trade in Tunisia. Renew. Sustain. Energy Rev. 2015, 47, 173-185. [CrossRef]

23. Menegaki, A.N.; Tugcu, C.T. Energy Consumption and Sustainable Economic Welfare in G7 Countries; A Comparison with the Conventional Nexus. Renew. Sustain. Energy Rev. 2017, 69, 892-901. [CrossRef]

24. Menegaki, A.; Tiwari, A. The Index of Sustainable Economic Welfare in the Energy-Growth Nexus for American Countries. Ecol. Indic. 2017, 72, 494-509. [CrossRef]

25. Amri, F. Intercourse across Economic Growth, Trade and Renewable Energy Consumption in Developing and Developed Countries. Renew. Sustain. Energy Rev. 2017, 69, 527-534. [CrossRef]

26. Bulut, U.; Inglesi-Lotz, R. Which Type of Energy Drove Industrial Growth in the US from 2000 to 2018? Energy Rep. 2019, 5, 425-430. [CrossRef]

27. Quitzow, R.; Bersalli, G.; Eicke, L.; Jahn, J.; Lilliestam, J.; Lira, F.; Marian, A.; Süsser, D.; Thapar, S.; Weko, S.; et al. The COVID-19 Crisis Deepens the Gulf between Leaders and Laggards in the Global Energy Transition. Energy Res. Soc. Sci. 2021, 74, 101981. [CrossRef]

28. Khanna, M. COVID-19: A Cloud with a Silver Lining for Renewable Energy? Appl. Econ. Perspect. Policy 2021, $43,73-85$. [CrossRef] 
29. IEA Global Energy Review 2020-Analysis and Key Findings. A Report by the International Energy Agency. Available online: https: / / www.iea.org/reports/global-energy-review-2020 (accessed on 23 November 2021).

30. Werth, A.; Gravino, P.; Prevedello, G. Impact Analysis of COVID-19 Responses on Energy Grid Dynamics in Europe. Appl. Energy 2021, 281, 116045. [CrossRef]

31. Dharani, M.; Hassan, M.K.; Rabbani, M.R.; Huq, T. Does the COVID-19 Pandemic Affect Faith-Based Investments? Evidence from Global Sectoral Indices. Res. Int. Bus. Financ. 2022, 59, 101537. [CrossRef]

32. Alam, M.N.; Alam, M.S.; Chavali, K. Stock Market Response during COVID-19 Lockdown Period in India: An Event Study. J Asian Financ. Econ. Bus. 2020, 7, 131-137. [CrossRef]

33. Kilpeläinen, S. Developing Nordic Cooperation in Renewable Electricity Policy: Exploring Views from Finland and Sweden. Politics Gov. 2020, 8, 44-52. [CrossRef]

34. Spasova, D.; Braungardt, S. Building a Common Support Framework in Differing Realities—Conditions for Renewable Energy Communities in Germany and Bulgaria. Energies 2021, 14, 4693. [CrossRef]

35. Keček, D.; Mikulić, D.; Lovrinčević, Ž. Deployment of Renewable Energy: Economic Effects on the Croatian Economy. Energy Policy 2019, 126, 402-410. [CrossRef]

36. Miškinis, V.; Galinis, A.; Konstantinavičiūte, I.; Lekavičius, V.; Neniškis, E. The Role of Renewable Energy Sources in Dynamics of Energy-Related GHG Emissions in the Baltic States. Sustainability 2021, 13, 10215. [CrossRef]

37. Tanil, G.; Jurek, P. Policies on Renewable Energy at the European and National Level of Governance: Assessing Policy Adaptation in the Czech Republic. Energy Rep. 2020, 6, 548-553. [CrossRef]

38. Menegaki, A.N. Growth and Renewable Energy in Europe: A Random Effect Model with Evidence for Neutrality Hypothesis Energy Econ. 2011, 33, 257-263. [CrossRef]

39. Kasman, A.; Duman, Y.S. $\mathrm{CO}_{2}$ Emissions, Economic Growth, Energy Consumption, Trade and Urbanization in New EU Member and Candidate Countries: A Panel Data Analysis. Econ. Model. 2015, 44, 97-103. [CrossRef]

40. Presno, M.J.; Landajo, M. EU-28's Progress toward the 2020 Renewable Energy Share: A Club Convergence Analysis. Environ. Sci. Pollut. Res. 2021, 28, 66830-66844. [CrossRef]

41. Salim, R.A.; Rafiq, S. Why Do Some Emerging Economies Proactively Accelerate the Adoption of Renewable Energy? Energy Econ. 2012, 34, 1051-1057. [CrossRef]

42. Omri, A.; Daly, S.; Nguyen, D.K. A Robust Analysis of the Relationship between Renewable Energy Consumption and Its Main Drivers. Appl. Econ. 2015, 47, 2913-2923. [CrossRef]

43. Irandoust, M. The Renewable Energy-Growth Nexus with Carbon Emissions and Technological Innovation: Evidence from the Nordic Countries. Ecol. Indic. 2016, 69, 118-125. [CrossRef]

44. Soava, G.; Mehedintu, A.; Sterpu, M.; Raduteanu, M. Impact of Renewable Energy Consumption on Economic Growth: Evidence from European Union Countries. Technol. Econ. Dev. Econ. 2018, 24, 914-932. [CrossRef]

45. Radmehr, R.; Henneberry, S.R.; Shayanmehr, S. Renewable Energy Consumption, $\mathrm{CO}_{2}$ Emissions, and Economic Growth Nexus: A Simultaneity Spatial Modeling Analysis of EU Countries. Struct. Chang. Econ. Dyn. 2021, 57, 13-27. [CrossRef]

46. Lee, J.W. Long-Run Dynamics of Renewable Energy Consumption on Carbon Emissions and Economic Growth in the European Union. Int. J. Sustain. Dev. World Ecol. 2019, 26, 69-78. [CrossRef]

47. Li, Q.; Cherian, J.; Shabbir, M.; Sial, M.; Li, J.; Mester, I.; Badulescu, A. Exploring the Relationship between Renewable Energy Sources and Economic Growth. The Case of SAARC Countries. Energies 2021, 14, 520. [CrossRef]

48. Al-Mulali, U.; Fereidouni, H.G.; Lee, J.Y.M. Electricity Consumption from Renewable and Non-Renewable Sources and Economic Growth: Evidence from Latin American Countries. Renew. Sustain. Energy Rev. 2014, 30, 290-298. [CrossRef]

49. Magazzino, C.; Mele, M.; Morelli, G. The Relationship between Renewable Energy and Economic Growth in a Time of COVID-19: A Machine Learning Experiment on the Brazilian Economy. Sustainability 2021, 13, 1285. [CrossRef]

50. Afsharzade, N.; Papzan, A.; Ashjaee, M.; Delangizan, S.; Passel, S.; Azadi, H. Renewable Energy Development in Rural Areas of Iran. Renew. Sustain. Energy Rev. 2016, 65, 743-755. [CrossRef]

51. Gökgöz, F.; Güvercin, M.T. Energy Security and Renewable Energy Efficiency in EU. Renew. Sustain. Energy Rev. 2018, 96, 226-239. [CrossRef]

52. Adom, P.K.; Amuakwa-Mensah, F.; Agradi, M.P.; Nsabimana, A. Energy Poverty, Development Outcomes, and Transition to Green Energy. Renew. Energy 2021, 178, 1337-1352. [CrossRef]

53. Chen, K.; Wang, M.; Huang, C.; Kinney, P.; Anastas, P. Air Pollution Reduction and Mortality Benefit during the COVID-19 Outbreak in China. Lancet Planet. Health 2020, 4, e210-e212. [CrossRef]

54. Kuzemko, C.; Bradshaw, M.; Bridge, G.; Goldthau, A.; Jewell, J.; Overland, I.; Scholten, D.; Van de Graaf, T.; Westphal, K. COVID-19 and the Politics of Sustainable Energy Transitions. Energy Res. Soc. Sci. 2020, 68, 101685. [CrossRef]

55. Aruga, K.; Islam, M.M.; Jannat, A. Effects of COVID-19 on Indian Energy Consumption. Sustainability 2020, 12, 5616. [CrossRef]

56. Bahmanyar, A.; Estebsari, A.; Ernst, D. The Impact of Different COVID-19 Containment Measures on Electricity Consumption in Europe. Energy Res. Soc. Sci. 2020, 68, 101683. [CrossRef]

57. Hosseini-Fashami, F.; Motevali, A.; Nabavi-Pelesaraei, A.; Hashemi, S.J.; Chau, K. Energy-Life Cycle Assessment on Applying Solar Technologies for Greenhouse Strawberry Production. Renew. Sustain. Energy Rev. 2019, 116, 109411. [CrossRef]

58. Eroğlu, H. Effects of COVID-19 Outbreak on Environment and Renewable Energy Sector. Environ. Dev. Sustain. 2021, 23, 4782-4790. [CrossRef] 
59. Bhuiyan, M.A.; An, J.; Mikhaylov, A.; Moiseev, N.; Danish, M.S.S. Renewable Energy Deployment and COVID-19 Measures for Sustainable Development. Sustainability 2021, 13, 4418. [CrossRef]

60. WEF. Fostering Effective Energy Transition; Insight Report, 2020 Edition; WEF: Cologny, Switzerland, 2020.

61. PEP2040 Energy Policy of Poland until 2040; Extract; Ministry of Climate and Environment: Warsaw, Poland, 2021.

62. Fu, Q.; Álvarez-Otero, S.; Sial, M.S.; Comite, U.; Zheng, P.; Samad, S.; Oláh, J. Impact of Renewable Energy on Economic Growth and CO2 Emissions-Evidence from BRICS Countries. Processes 2021, 9, 1281. [CrossRef]

63. Shahbaz, M.; Loganathan, N.; Zeshan, M.; Zaman, K. Does Renewable Energy Consumption Add in Economic Growth? An Application of Auto-Regressive Distributed Lag Model in Pakistan. Renew. Sustain. Energy Rev. 2015, 44, 576-585. [CrossRef]

64. Ntanos, S.; Skordoulis, M.; Kyriakopoulos, G.; Arabatzis, G.; Chalikias, M.; Galatsidas, S.; Batzios, A.; Katsarou, A. Renewable Energy and Economic Growth: Evidence from European Countries. Sustainability 2018, 10, 2626. [CrossRef]

65. Czerniak, A.; Stefański, M. Small and Medium Enterprises in Poland-Obstacles and Development; Polityka Insight Research 2021; Polityka Insight: Warsaw, Poland, 2021.

66. European Commission. 2019 SBA Fact Sheet E Scoreboard; European Commission: Brussels, Belgium, 2019.

67. Sorrell, S. Reducing Energy Demand: A Review of Issues, Challenges and Approaches. Renew. Sustain. Energy Rev. 2015, 47, 74-82. [CrossRef]

68. Manigandan, P.; Alam, M.S.; Alharthi, M.; Khan, U.; Alagirisamy, K.; Pachiyappan, D.; Rehman, A. Forecasting Natural Gas Production and Consumption in United States-Evidence from SARIMA and SARIMAX Models. Energies 2021, 14, 6021. [CrossRef]

69. Matei, I. Is There a Link between Renewable Energy Consumption and Economic Growth? A Dynamic Panel Investigation for the OECD Countries. Rev. D'economie Polit. 2017, 127, 985-1012. [CrossRef] 